\title{
The Impact of Enterprise Resources Planning Implementation in Cross-Functional for Sharing Knowledge and Quality Information in Preparing the Financial Statements
}

\author{
Zeplin Jiwa Husada Tarigan ${ }^{1 *}$, Sautma Ronni Basana ${ }^{2}$, and Widjojo Suprapto ${ }^{3}$ \\ ${ }^{1}$ Master of Management Department, Faculty of Business and Economics, Petra Christian University, \\ J1. Siwalankerto No.121-131, Surabaya, 60236, Indonesia \\ ${ }^{2}$ Financial Management, Faculty of Business and Economics, Petra Christian University, \\ Jl. Siwalankerto No.121-131, Surabaya, 60236, Indonesia \\ ${ }^{3}$ Business of Management Department, Faculty of Business and Economics, \\ Petra Christian University, Jl. Siwalankerto No.121-131, Surabaya, 60236, Indonesia
}

\begin{abstract}
Enterprise Resources Planning (ERP) has been adopted by the manufacturing and service industries to improve the performance of the company. It helps construct the company's financial statements. There are two main questions: first, how the influence of implementing ERP can enhance the good integration and second, how sharing between departments can affect the quality of information so that the process of making the company's monthly financial reports on time. For company management in East Java, one successful indicator is the on-schedule monthly financial reports. Based on the results there are 102 questionnaires returned, but only 58 replies are coming from the finance and accounting department. Eight questionnaires were incomplete, therefore discharged. As many as 50 questionnaires can be further processed. The results of this study find that ERP implementation gives a positive impact to cross-functional departments and sharing knowledge. However, the impact of cross-functional department does not affect the sharing knowledge because many heads of departments find it difficult to discuss and understand business processes in other departments. The cross functional departments and the sharing of information have a significant influence on the quality of company information. Last, cross-functional departments and the quality of information affect the financial statement.
\end{abstract}

Key words: Financial report, information sharing, integrated information technology, process integration.

${ }^{*}$ Corresponding author: zeplin@peter.petra.ac.id 


\section{Introduction}

To win the global competition, many companies try to increase their productivities and performance. Most of the time, the company management implement the information technology to increase the company performance. A research conducted by Bradley [1] states that the implementation of Enterprise Resources Planning (ERP) gives certain impacts to the whole process in the organization and to the company employee to understand a new business system using software and hardware. Many manufacturing companies are still organized partially or departmentally where a manager controls directly through monitoring to the operational fields to know the target achievement of production. Such a condition requires a lot of a certain level in the company to be able to control the employees directly. Up to now, the problem lies on the companies that have not yet integrated the information system in the management. So far, the companies are supported only by individual activities at each department. This fact can bring some misunderstandings in communication of data between one department and others. Since each individual submits the data in his isolated department, it can cause a fundamental difference in the delivery of data, and it may take a long time to clarify the differences. This condition will be likely less time consuming if the company integrates the functions with ERP.

The ERP program helps companies with many broad business processes using database and segmented management reporting tools. Business processes are some activities that need one or several inputs to produce outputs as the consumer value. Baheshti [2] states that the ERP technology can integrate marketing function, production, logistics, finance, human resources, and other functions.

The company strategies set goals and instructions on how organizational capabilities can be the best tool to achieve improved competitive position. The strategic design process is a matter that can increase the competitiveness of the company, because it can provide clues to accomplish the process and the flow of the integrated process. It can also provide variations of work achievements, material flows, workers, and information as the competitive resources. A stronger competition forces the managers to find a strategy to defend and to increase the competitive advantage of the company. The theory of resources indicates unique tangible and intangible resources that are owned by the company to increase the competitiveness of the company. The resources must possess unique values so that the competitor cannot imitate the uniqueness and it becomes the foundation for the competitive advantage [3].

Implementing ERP in a company is very important. Organizational commitment can increase the company performance because ERP creates information sharing, which is a part of knowledge sharing to produce quality information suitable for the company business design processes. Jones et al. [4] states that there are eight dimensions of culture that give impacts to knowledge sharing in a company and they are: the basis of truth and rationality; motivation; orientation to change, orientation to work; orientation to collaboration; control, coordination, and responsibility; orientation and focus; and nature of time horizon. A research by Law and Ngai [5] reveals that knowledge sharing and learning are very important to the success of an industry in running the business process. Hu et al. [6] also reveals that knowledge sharing has become the culture for the company teamwork in giving better service innovation. Implementing ERP has become a better investment as the information flow is running effectively and efficiently. It can also make the cross functional integration in a company better because one department and others are connected with one single data base.

A research conducted by Liao and Cuang [7] states that the individual knowldge formed by agreement and consistency factors correlates with the effectiveness in commitment to 
build communication and relation through knowledge sharing. Wasko and Faraj [8] say that a capable teamwork is formed through the ability of each person to communicate and relate with others so that everyone contributes according to the expertise for some period of time. An individual learning orientation is the first step in sharing knowledge and collaboration for every employees in a company. Communication built by each employee will gradually form a unity and coherence about the organizational goals among the workgroup [9]. The group members' perception about their contribution to the distribution of information on the company can bring benefits to the organization. The shared information among departments can create quality information.

Quality information contains accuracy, timelines, data relevancy, and completeness [10]. Thw top management supports are needed to integrate data across departments using ERP technology. Good data integration across departments will provide good quality information because it is not distorted and delayed. Top managers require good quality information to make the financial statement. The quality information can be the numbers of purchased orders by the customers, daily production reports, routinely monitored good supplies, and on-going inventory on the production floor. The quality of information can reduce uncertainty and bring improvements for the company to increase profitability [11].

\section{Research Framework}

Companies try to implement ERP in order to improve the performance. ERP implementation can use a single data base and can integrate all departments so that the entry of data in marketing can be used by all departments in a timely manner. Data integration in the company is a form of cross functional departments. Good integration among departments can increase information sharing with other departments through a process of communication and coordination so it can reduce the distortion of the data, and improve the quality of information. As the result, quality information can speed up the process of making the company financial statement.

The problems so far with the ERP system in most companies occur monthly when the accounting department does the closing entry. There are many unavailable data because they are not yet reported to the financial department, such as during the material retrieval from the production warehouse, the warehouse delivery has not performed the data entry so the amount of production has not been recorded yet. Besides, many other departments are entering the data without checking them in advance, so that some data are not based on the reality of production. This condition forces the financial department to verify the relevancy of the data one by one to different divisions, which ultimately causes tardiness to the report preparation. Under such circumstances in the companies, the researcher proposes the following model that is described in Figure 1.

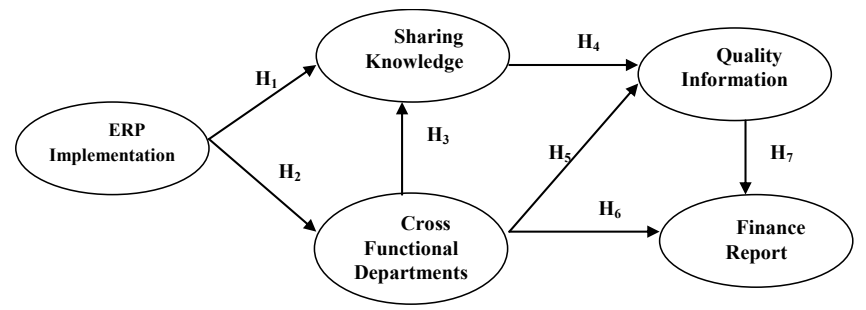

Fig. 1. Research framework 
Based on the model in Figure. 1, there are several hypothese proposed for this research:

H1: ERP implementation gives positive influences on sharing knowledge in manufacturing industries in East Java, Indonesia

H2: ERP implementation gives positive influences on cross functional departments in manufacturing industries in East Java, Indonesia

H3: Sharing knowledge brings positive influences on cross functional departments in manufacturing industries in East Java, Indonesia

H4: Sharing knowledge gives positive influences on quality information in manufacturing industries in East Java, Indonesia

H5: Cross functional departments has positive influences on quality information in manufacturing industries in East Java, Indonesia

H6: Cross functional department has positive influences on financial statement in manufacturing industries in East Java, Indonesia

H7: Quality information gives positive influences on financial statement in manufacturing industries in East Java, Indonesia

\section{Research Methods}

Data are collected from manufacturing companies that have implemented the ERP technology. There are several ways to collect the data, among others are the questionnaire and the interviews. The questionnaire is used to collect the descriptive data to test the hypothesis and assessment model. The questionnaire is designed with closed questions, that means the respondents are limited to select one or two already given answers. Each questionnaire is for one of the key users in one company, so one questionnaire is for one company. The questionnaire distribution is conducted by visiting each company, explaning the questionnaire to one key user, and deciding the interview date. While picking up the questionnaires, the interviews are conducted by questioning the key users to describe the real conditionof the company.

For this research, the emphasis is on the data collection by interviewing the key users while filling in the questionnaire. During the interview, the key users are inquired to observe and analyze the real conditions of the company, and then put them in the questionnaire. The scale of measurement used in this research is a Likert scale, with the score of one to five. To test the hypotheses and surrender a fit model, this research is using the Partial Least Square (PLS) with the help of application program Software Smart PLS to calculate. The reason to use this software is that there is a tiered structure of relationship among variables [12].

Variables for ERP implementation are: the ability of the management to communicate clearly the importance of ERP for the company, the constant collaboration built by the management in implementing ERP, the ability of the management to create things as form of creative improvement, and the ability of the management to communicate effectively and well with the ERP team. Indicators for knowledge sharing are the sharing atmosphere among departments, the existence of a good effort in the sharing of knowledge among departments, the enthusiasm of each department to share knowledge with other departments, and the existence of the facility in knowledge sharing among departments inside the company. Indicators for cross functional departments are the integration of data among departments within the company, the regular meetings between the departments within the company, the existence of the document control system among the departments within the company, and the real-time connections among departments. Variables for quality information are the availability of the required data among departments in the ERP system, the data within the ERP considered as accurate as needed, the relevancy of the 
existing data in the ERP with the needy departments, and the comprehensiveness of the data in the ERP. Indicators for financial statements are the necessity of the financial statements on the ERP, the description in financial statements reflecting the activities of the company's operation, the financial statements providing the company's operational performance, and the usage of the financial reports in ERP by all parties.

\section{Result and analysis}

The respondents for this research are gathered from various manufacturing industries in East Java, Indonesia, particularly in the areas of Surabaya, Mojokerto, Gresik, Sidoarjo, and Pasuruan. From a total of 110 questionnaires, only 102 questionnaires are returned. From the returned questionnaires, those from the accounting and finance department are only 58 respondents but eight questionnaires are incomplete, so as many as 50 questionnaires are further processed.

The data processing is using PLS, with regard to the value of goodness of fit outer model. First, convergent validity, that is a correlation between the reflexive indicator score and the latent variable score, is used. For this research, loading of 0.5 to 0.6 is considered fair, because it is still in the early stage of measurement scale development and the numbers of indicators per construct is not large, ranging from three to seven indicators. Second, composite reliability is used, that is a block indicator that measures the internal consistency of construct forming indicators and shows the degree that indicates common latent. The acceptable value limit for the degree of composite reliability is 0.7 , although not an absolute standard. Based on Table 1 below, the convergent validity reveals the relationship between the indicators with each variable as indicated by the value of the weighting factor. Based on Table 1, all variables have complied with the convergent validity as all loading factors are above 0.5 .

Table 1. Convergent validity

\begin{tabular}{|c|c|c|c|}
\hline Outer loading & ERP & Outer loading & Cross \\
\hline X.1.1. & 0.735 & X.3.1. & 0.666 \\
\hline X.1.2. & 0.647 & X.3.2. & 0.635 \\
\hline X.1.3. & 0.871 & X.3.3. & 0.815 \\
\hline X.1.4. & 0.638 & X.3.4. & 0.465 \\
\hline Outer loading & Sharing & Outer loading & Quality \\
\hline X.2.1. & 0.576 & X.4.1. & 0.835 \\
\hline X.2.2. & 0.903 & X.4.2. & 0.901 \\
\hline X.2.3. & 0.707 & X.4.3. & 0.727 \\
\hline X.2.4. & 0.764 & X.4.4. & 0.782 \\
\hline Outer loading & Finance & & \\
\hline X.5.1. & 0.884 & & \\
\hline X.5.2. & 0.927 & & \\
\hline X.5.3. & 0.905 & & \\
\hline X.5.4. & 0.940 & & \\
\hline
\end{tabular}

Table 2. Composite reliability

\begin{tabular}{cc}
\hline Variable & Composite reliability \\
\hline ERP & 0.817 \\
Sharing & 0.831 \\
Cross & 0.746 \\
Quality & 0.886 \\
Finance & 0.953 \\
\hline
\end{tabular}


The prerequisite values of composite reliability (Table 2) are met by all variables, with the values above 0.7 . The structural model is evaluated using the $\mathrm{R}$-square dependent latent variables with similar interpretation of regression. The Q-square predictive relevance for the construct model measures how well the observed values generated by the model with also its parameter. Q-square value greater than zero indicates that the structural model has predictive relevance; on the other hand, the Q-square value less than zero indicates that the model lacks predictive relevance.

Table 3. R-Square value

\begin{tabular}{|c|c|}
\hline Variable & R-square \\
\hline ERP & \\
\hline Sharing & 0.535 \\
\hline Cross & 0.792 \\
\hline Quality & 0.281 \\
\hline Finance & 0.786 \\
\hline
\end{tabular}

Based on Table 3 below, it is obtained that the value of Q-square is 0.952 , which is greater than zero, and indicates that the model has the predictive relevance.

Table 4. Result for inner weight output PLS

\begin{tabular}{lcccc}
\hline & $\begin{array}{c}\text { original sample } \\
\text { estimate }\end{array}$ & $\begin{array}{c}\text { mean of } \\
\text { subsamples }\end{array}$ & $\begin{array}{c}\text { standard } \\
\text { deviation }\end{array}$ & T-statistic \\
\hline ERP -> Sharing & 0.732 & 0.744 & 0.068 & 10.787 \\
ERP -> Cross & 0.821 & 0.833 & 0.098 & 8.376 \\
Cross -> Sharing & 0.091 & 0.089 & 0.106 & 0.855 \\
Sharing -> Quality & 0.385 & 0.343 & 0.200 & 1.921 \\
Cross -> Quality & 0.718 & 0.630 & 0.277 & 2.592 \\
Cross -> Finance & 0.326 & 0.426 & 0.207 & 1.945 \\
Quality -> Finance & 0.898 & 0.897 & 0.059 & 15.202 \\
\hline
\end{tabular}

The first statistical hypothesis for the inner model is the exogenous latent variable to endogenous. The first hypothesis $\left(\mathrm{H}_{1}\right)$ of this research states a presumption that the ERP implementation in a company will create sharing knowledge. Statistically, this hypothesis relates to the $\gamma 1$ test result that can be formulated with statistical hypothesis as follows:

$\mathrm{H}_{0}: \gamma_{1}=0$ There is no significant influence in the ERP implementation on sharing knowledge.

$\mathrm{H}_{1}: \gamma_{1} \neq 0$ There is a significant influence in the ERP implementation on sharing knowledge.

Based on Table 4, the gamma coefficient $\left(\gamma_{1}\right)$ is 0.732 , and t-statistic is 10.787 , which is higher than the t-table of 1.96 , therefore $\mathrm{H}_{1}$ is accepted. It means there is a significant influence in the ERP implementation on the sharing knowledge with the significant level of 0.05 .

The second statistical hypothesis for the inner model is the exogenous latent variable to endogenous. The second hypothesis $\left(\mathrm{H}_{2}\right)$ assumes that the ERP implementation in a company will affect cross functional departments. Statistically, this hypothesis relates to the $\gamma_{2}$ test results that can be formulated with statistical hypothesis as follows:

$\mathrm{H}_{0}: \gamma_{2}=0$ There is no significant influence in the ERP implementation on cross functional department.

$\mathrm{H}_{2}: \gamma_{2} \neq 0 \quad$ There is a significant influence in the ERP implementation on cross functional department. 
Based on Table 4, the gamma coefficient $\left(\gamma_{2}\right)$ is 0.821 , and t-statistic is 8.376 , which is higher than the t-table of 1.96, therefore $\mathrm{H}_{2}$ is accepted. It means there is a significant influence in the ERP implementation on the cross functional departments with the significant level of 0.05 .

The third statistical hypothesis for the inner model is the exogenous latent variable to endogenous. The third hypothesis $\left(\mathrm{H}_{3}\right)$ presumes that the cross functional departments in a company will affect the sharing knowledge. Statistically, this hypothesis relates to the test result of $\beta_{3}$ that can be formulated with statistical hypothesis as follows:

$\mathrm{H}_{0}: \beta_{3}=0$ There is no significant influence in the cross functional departments on sharing knowledge.

$\mathrm{H}_{3}: \beta_{3} \neq 0$ There is a significant influence in the cross functional departments on sharing knowledge.

Based on Table 4, the beta coefficient $\left(\beta_{3}\right)$ is 0.091 , and t-statistic is 0.855 , which is lower than the t-table of 1.96 , therefore $\mathrm{H}_{0}$ is accepted. It means there is no significant influence in the cross functional departments on the sharing knowledge with the significant level of 0.1 .

The fourth statistical hypothesis for the inner model is the exogenous latent variable to endogenous. The fourth hypothesis $\left(\mathrm{H}_{4}\right)$ states that there is an influence of the sharing knowledge on quality information. Statistically, this hypothesis relates to the test results of $\beta_{4}$ which can be formulated with statistical hypothesis as follows:

$\mathrm{H}_{0}: \beta_{4}=0$ There is no significant influence of the sharing knowledge on quality information.

$\mathrm{H}_{4}: \beta_{4} \neq 0$ There is a significant influence of the sharing knowledge on quality information.

Based on Table 4 , the beta coefficient $\left(\beta_{4}\right)$ is 0.385 , and t-statistic is 1.921 , which is higher than the t-table of 1.65 , therefore $\mathrm{H}_{4}$ is accepted. It means there is a significant influence of the sharing knowledge on quality information with the significant level of 0.1 .

The fifth statistical hypothesis for the inner model is the exogenous latent variable to endogenous. The fifth hypothesis $\left(\mathrm{H}_{5}\right)$ states that there is an influence of the cross functional department on the quality information. Statistically, this hypothesis relates to the test results of $\beta_{5}$ which can be formulated with statistical hypothesis as follows:

$\mathrm{H}_{0}: \beta_{5}=0$ There is no significant influence of the cross functional departments on the quality information.

$\mathrm{H}_{5}: \beta_{5} \neq 0$ There is a significant influence of the cross functional departments on the quality information.

Based on Table 4 , the beta coefficient $\left(\beta_{5}\right)$ is 0.718 , and t-statistic is 2.592 , which is higher than the t-table of 1.96 , therefore $\mathrm{H}_{5}$ is accepted. It means there is a significant influence of the cross functional departments on the quality information with the significant level of 0.05 .

The sixth statistical hypothesis for the inner model is the exogenous latent variable to endogenous. The sixth hypothesis $\left(\mathrm{H}_{6}\right)$ indicates that there is an influence of the cross functional department on financial statement. Statistically, this hypothesis relates to the test results of $\beta_{6}$ which can be formulated with statistical hypothesis as follows:

$\mathrm{H}_{0}: \beta_{6}=0$ There is no significant influence of the cross functional departments on financial statement.

$\mathrm{H}_{6}: \beta_{6} \neq 0$ There is a significant influence of the cross functional departments on financial statement. 
Based on Table 4, the beta coefficient $\left(\beta_{6}\right)$ is 0.326 , and t-statistic is 1.945 , which is higher than the t-table of 1.65 , therefore $\mathrm{H}_{6}$ is accepted. It means there is a significant influence of the cross functional departments on the financial statement with the significant level of 0.1 .

The seventh statistical hypothesis for the inner model is the exogenous latent variable to endogenous. The seventh hypothesis $\left(\mathrm{H}_{7}\right)$ assumes that there is an influence of the quality information on the financial statement. Statistically, this hypothesis relates to the test results of $\beta_{7}$ which can be formulated with statistical hypothesis as follows:

$\mathrm{H}_{0}: \beta_{7}=0$ There is no significant influence of the quality information on the financial statement.

$\mathrm{H}_{7}: \beta_{7} \neq 0$ There is a significant influence of the quality information on the financial statement.

Based on Table 4 , the beta coefficient $\left(\beta_{7}\right)$ is 0.898 , and t-statistic is 15.202 , which is higher than the t-table of 1.96 , therefore $\mathrm{H}_{7}$ is accepted. It means there is a significant influence of the quality information on the financial statement with the significant level of 0.05 .

\section{Conclusion}

The purpose of this study is to examine the impact of ERP implementation in crossfunctional for knowledge sharing and quality information in preparing the financial statements. The result of the study demonstrated the following findings. First, ERP implementation influence the. Second, the ERP implementation affects cross functional analysis. Third, the cross functional cooperation influences the sharing knowledge. Fourth, knowledge sharing influences the quality information, Fifth, cross functional affects the quality information. Sixth, cross functional influence financial statement. The last finding, quality information affects the financial statement. This study provides an insight for the manager how to improve the financial statement through the implementation of ERP, cross functional, knowledge sharing, and provision of quality information. This study also contributes to the on-going research in the field supply chain management with the involvement of the financial issue.

\section{References}

1. J. Bradley, Int. J. Account. Inf. Syst., 9,3:175-200(2008). https://www.sciencedirect.com/science/article/pii/S1467089508000377

2. H.M. Beheshti, Manag. Res. News, 29,4:184-193(2006). https://www.emeraldinsight.com/doi/abs/10.1108/01409170610665040

3. R. Garud, A. Kumaraswamy, MIS Q., 29,1:9-33(2005). $\underline{\mathrm{http}} / / /$ digitalcommons.wcupa.edu/cgi/viewcontent.cgi? article $=1002 \&$ context $=\mathrm{ma}$ n facpub

4. M.C. Jones, M. Cline, S. Ryan, Decis. Support Syst., 41,2:411-434(2006). https://www.sciencedirect.com/science/article/pii/S0167923604001630

5. C.C.H. Law, E.W.T. Ngai, Expert Syst. Appl., 34,4:2342-2349(2008). https:/www.sciencedirect.com/science/article/pii/S0957417407001273

6. M.L.M. Hu, J.S. Horng, Y.H.C. Sun, Tour. Manag., 30,1:41-50(2009). https://www.sciencedirect.com/science/article/pii/S0261517708000769

7. H. Liao, A. Chuang, Acad. Manag. J., 47,1:41-58(2004). https://journals.aom.org/doi/abs/10.5465/20159559 
8. M.M. Wasko, S. Faraj, MIS Q., 29,1:35-57(2005).

https://pdfs.semanticscholar.org/158e/131aac4ed0751a0e6752f8618b4528da879 b.pdf

9. L. Nelson, G. Tonks, Res. Pract. Hum. Resour. Manag., 15,1:22-36(2007). https://eprints.utas.edu.au/4359/

10. S. Li, B. Lin, Decis. Support Syst., 42,3:1641-1656(2006). https://www.sciencedirect.com/science/article/pii/S0167923606000327

11. R. Omar, T. Ramayah, M.-C. Lo, T.Y. Sang, R. Siron, African J. Bus. Manag., 4,12:2486-2499(2010).

http://www.academicjournals.org/app/webroot/article/article1380789448_Omar $\% 20$ et $\% 20$ al.pdf

12. I. Ghozali, Structural equation modeling metode alternatif dengan partial least square, [Structural equation modeling alternative methods with partial least square], Badan Penerbit Universitas Diponegoro, Indonesia (2008), p. 244. [in Bahasa Indonesia]. https://www.goodreads.com/book/show/24487599-structuralequation-modelling-metode-alternatif-dengan-partial-least-squ 